\title{
Myocardial phenotype changes in heart failure: cellular and subcellular adaptations and their functional significance
}

Medizinische Klinik III, Universität Freiburg, Germany $G$ Hasenfuss

H Just

Correspondence to: Dr G Hasenfuss, Universität Freiburg, Medizinische Klinik III, Hugstetter Strasse 55, 79106 Freiburg, Germany.

\author{
Gerd Hasenfuss, Hanjörg Just
}

\begin{abstract}
Myocardial growth in response to mechanical and neurohumoral stimuli In most cases heart failure is the fatal result of chronic pressure or volume overload due to valvar disease, arterial hypertension, and myocardial infarction. ${ }^{1}$ The myocardium responds to an increase in load-that is, in wall stress, by development of hypertrophy. This might be considered to be a compensatory response, as according to the law of Laplace, myocardial wall stress decreases with increasing wall thickness. Although in some way adaptive, part of this response is pathological in that it is associated with abnormalities in both diastolic and systolic function and by still unknown mechanisms, may ultimately lead to myocardial failure. With the development of failure the disease process that was initially localised at the heart generalises and many organs will be affected by activation of the renin-angiotensin system and the sympathetic nervous system. In the case of an aetiology other than pressure or volume overload, such as dilated cardiomyopathy, the initial pathological process in the myocardium is less well understood. With the development of failure, the consecutive changes seem to be rather uniform and independent of the aetiology.

Myocardial hypertrophy and failure involve quantitative and qualitative modifications of
\end{abstract}

the genomic expression. In quantitative changes, there is an overall increase in the cardiac expressions of most genes, which finally leads to myocyte hypertrophy and fibroblast hyperplasia. Superimposed on this global response, qualitative changes in gene expression include a positive and negative modulation of cardiac specific genes and a shift in the expression of several isogenes towards a programme partially comparable with that expressed in the fetal heart (table).

Recently some of the mechanical stimuli, hormones, and growth factors that induce the quantitative and qualitative changes of gene expression as well as their subcellular pathways have been elucidated. Generally, the process of hypertrophy involves the expression of "immediate early genes" and "late responsive genes". The late responsive genes include the cardiac specific genes. The immediate early genes such as the protooncogenes c-myc, c-fos, c-jun, etc, the mRNA of which may be increased as early as several minutes after exposure to the stimulus, code for a rather complex group of oncoproteins that seem to induce and control gene expression in a rather non-specific way. ${ }^{31} 3233$

The pathological stimulus for altered gene expression has been investigated by several groups, who used neonatal and adult rat myocytes. They have shown that $a_{1}$ receptor

Altered gene expression in the failing human myocardium

\begin{tabular}{|c|c|c|}
\hline Subcellular system & Alteration in ph & ype \\
\hline $\begin{array}{l}\text { Sarcolemma: } \\
\text { L type } \mathrm{Ca}^{2+} \text { channel }\end{array}$ & Controversial & $\begin{array}{l}\text { Unaltered dihydropyridine binding sites in } \mathrm{DCM}^{2} \text {; unaltered peak } \mathrm{Ca}^{2+} \\
\text { current densities and current voltage relation in } \mathrm{DCM}^{2+} \text { and ICM }{ }^{3} ; \text { decreased } \\
\text { number of dihydropyridine binding sites and decreased mRNA in DCM and } \\
\text { ICM. }\end{array}$ \\
\hline $\begin{array}{l}\beta \text { Adrenoceptor } \\
\mathrm{G}_{\mathrm{i} \alpha} \text { protein }\end{array}$ & $\begin{array}{l}\text { Decreased } \\
\text { Increased }\end{array}$ & $\begin{array}{l}\text { Decreased } \beta_{1} \text { receptor radioligand binding and } \mathrm{mRNA} \text { in DCM and ICM. } \\
\text { Increased in DCM by pertussis toxin induced ADP ribosilation }{ }^{789} \text {; increased } \\
\text { in DCM and ICM by immunochemical quantification }{ }^{10} \text {; increased mRNA in } \\
\text { DCM and ICM. }\end{array}$ \\
\hline $\begin{array}{l}\mathrm{G}_{s a} \text { protein } \\
\mathrm{Na}^{+} / \mathrm{K}^{+} \text {ATPase } \\
\mathrm{Na}^{+} / \mathrm{Ca}^{2+} \text { exchanger } \\
\text { Sarcoplasmic reticulum }(S R) \text { : }\end{array}$ & $\begin{array}{l}\text { Unchanged } \\
\text { Unchanged } \\
\text { Increased }\end{array}$ & $\begin{array}{l}\text { Unaltered cholera toxin labelling. }{ }^{1012} \\
\text { Unchanged } \mathrm{H}^{3} \text { ouabain binding and } \mathrm{mRNA}^{13} \text { in } \mathrm{DCM} \text { and ICM. } \\
\text { Increased } \mathrm{mRNA} \text { and protein }{ }^{14} \text { in DCM and ICM. }\end{array}$ \\
\hline Ryanodine receptor & Controversial & $\begin{array}{l}\text { Decreased mRNA in } \mathrm{ICM}^{5} \text {; inverse correlation between mRNA and ANF } \\
\text { mRNA }^{15} \text { in DCM; normal function by single channel recordings in } \mathrm{DCM}^{16} \text {; } \\
\text { decreased caffeine response in DCM. }\end{array}$ \\
\hline $\mathrm{Ca}^{2+}-\mathrm{ATPase}$ & Decreased & $\begin{array}{l}\text { Decreased mRNA in DCM and ICM } \\
\text { DCM and ICM } ;^{14,19} \text { decreased SR Ca } \mathrm{C}^{2+} \text { uptake in homogenates from } \mathrm{DCM}^{20} \\
\text { in contrast: unchanged uptake in isolated SR vesicles from DCM. }\end{array}$ \\
\hline Phospholamban & Decreased & $\begin{array}{l}\text { Decreased mRNA by PCR in DCM }{ }^{22} \text {; inverse correlation between mRNA } \\
\text { and ANF } \text { mRNA }^{15} \text { in DCM. }\end{array}$ \\
\hline $\begin{array}{l}\text { Calsequestrin } \\
\text { Contractile proteins: }\end{array}$ & Unchanged & Unaltered mRNA concentrations in DCM and ICM. ${ }^{4}$ \\
\hline Myosin heavy chain & Unaltered & $\begin{array}{l}\text { No isoform shift (dominance of the } \beta \text { myosin heavy chain) in ventricular } \\
\text { myocardium. }{ }^{24}{ }^{25} \text { In contrast, isoform shift from } a \text { myosin heavy chain to } \beta \\
\text { myosin heavy chain in atrial tissue. } .^{23}\end{array}$ \\
\hline Myosin light chain & Altered & $\begin{array}{l}\text { Increased ventricular expression of atrial light chain } 1 \text { in } \mathrm{DCM}^{26} \text {; decreased } \\
\text { light chain } 2 \text { in DCM. }\end{array}$ \\
\hline $\begin{array}{l}\text { Actin } \\
\text { Troponin } \mathrm{T}\end{array}$ & $\begin{array}{l}\text { Unaltered } \\
\text { Altered }\end{array}$ & $\begin{array}{l}\text { No change in } \alpha \text { skeletal to } a \text { cardiac ratio mRNA in DCM and ICM. }{ }^{28} \\
\text { Increased expression of isoform } \operatorname{TnT}_{2 .}{ }^{29}{ }_{30}\end{array}$ \\
\hline
\end{tabular}

DCM, dilated cardiomyopathy; ICM, ischaemic cardiomyopathy; PCR, polymerase chain reaction; ANF, atrial natriuretic factor 
stimulation results in an increase of mRNA that encodes immediate early and late responsive genes and in development of myocardial hypertrophy..$^{34}$ Moderate development of hypertrophy has also been described after stimulation of $\beta$-adrenergic receptors. ${ }^{36}$ Furthermore, it was shown that different classes of peptide growth factors such as $\beta_{1}$ transforming growth factor $\left(\mathrm{TGF} \beta_{1}\right)$ and fibroblast growth factors (FGFs) induce expression of gene programmes resembling those seen during hypertrophy caused by pressure overload. ${ }^{37} 38$

With rat neonatal cardiocytes, Komuro et al found that stretching the cells increased within minutes the total cell RNA content and mRNA concentrations of c-fos and skeletal $a$ actin, followed by activation of protein synthesis. ${ }^{39} 40$ These authors further suggested that activation of protein kinase $\mathrm{C}$ may be involved in stretch induced protein synthesis. ${ }^{41}$ More recently, Sadoshima and Izumo found that in neonatal rat myocytes angiotensin II (AII), through activation of the $\mathrm{AT}_{1}$ receptor, induces expression of many immediate early genes. ${ }^{42}$ Then myocyte hypertrophy and fibroblast hyperplasia developed. These authors also showed that activation of protein kinase $\mathrm{C}$ may be the dominant pathway for AII induced gene expression. ${ }^{43}$

As AII mediated induction of gene expression closely resembles the situation when mechanical stress is applied to myocytes it might be speculated that local production of growth factor AII may be involved in stress induced myocyte hypertrophy.

This hypothesis is supported by molecular analyses showing mRNA expression of all elements of the renin-angiotensin system in peripheral organs including the heart. ${ }^{44}$ Moreover, enhanced myocardial mRNA expression for angiotensinogen and angiotensin converting enzyme (ACE) was found in several models of cardiac hypertrophy. ${ }^{46} 47$ Enhanced expression of ACE mRNA was also found in human hearts with end stage ischaemic or dilated cardiomyopathy ${ }^{48}$ As well as AII induced myocyte hypertrophy and fibroblast hyperplasia, interstitial fibrosis may also be mediated by an angiotensin induced rise in circulating aldosterone. ${ }^{49}$

\section{Modulation of cardiac specific gene expression in the failing heart CONTRACTILE PROTEINS}

The key element of development of myocardial force or shortening is the crossbridge cycle, in which the myosin crossbridge head attaches to actin, rotates in a manner that develops force or causes shortening with thick and thin filaments sliding past each other, and then detaches from the actin filament to start another crossbridge cycle. Alterations in the number of the crossbridges activated or the characteristics of the individual crossbridge cycle may have profound effects on the contractile performance of the heart muscle.

The total number of crossbridges available for activation may be reduced due to replace- ment of contractile proteins by connective tissue. This situation may be the prominent finding in ischaemic cardiomyopathy after a myocardial infarction. A substitution of contractile material by connective tissue may be of some relevance in other causes of heart failure as well. Hitzel et al in a morphometric study in control hearts described a nonmuscle tissue content of the myocardium of $4 \%{ }^{26}$ Non-muscle tissue content was increased to $23 \%$ in dilated cardiomyopathy and $25 \%$ in pressure overloaded myocardium. Accordingly, when the myosin content was quantified biochemically, a decrease of $20 \%$ was found in dilated cardiomyopathy. ${ }^{50}$ From these data it was concluded that the decrease in contractile protein content is less important in the contractile deficit of the failing heart than is disturbed crossbridge activation due to altered excitation-contraction coupling processes..$^{50}$

Profound alterations to the characteristics of the individual crossbridge cycle have been found in animal models of myocardial hypertrophy. ${ }^{51-56}$ In these studies reduced activity of myosin ATPase or myofibrillar ATPase, maximum shortening velocity, and increased economy of isometric force development occurred in the hypertrophied myocardium. The increased economy has been interpreted as prolonged attachment time of the crossbridges and reduced crossbridge cycling rate..$^{52}$ The changes within the crossbridge behaviour have been attributed to changes in the myosin isoform from $V_{1}$ to $V_{3}$; the $V_{1}$ isoform consists of $a$ myosin heavy chain and the $\mathrm{V}_{3}$ isoform of the $\beta$ myosin heavy chain. ${ }^{53}$ In the hypertrophied and failing human heart, similar changes in the crossbridge cycle to those found in hypertrophied hearts of small mammals have been found, although an $a / \beta$ myosin heavy chain heterogeneity does not seem to play an important part in the human ventricular myocardium (fig 1). ${ }^{5056-59}$ Normal human ventricular myocardium primarily consists of one myosin isoform, $V_{3}$ ( $\beta$ myosin heavy chain), and no significant isoform shift occurs in hypertro-

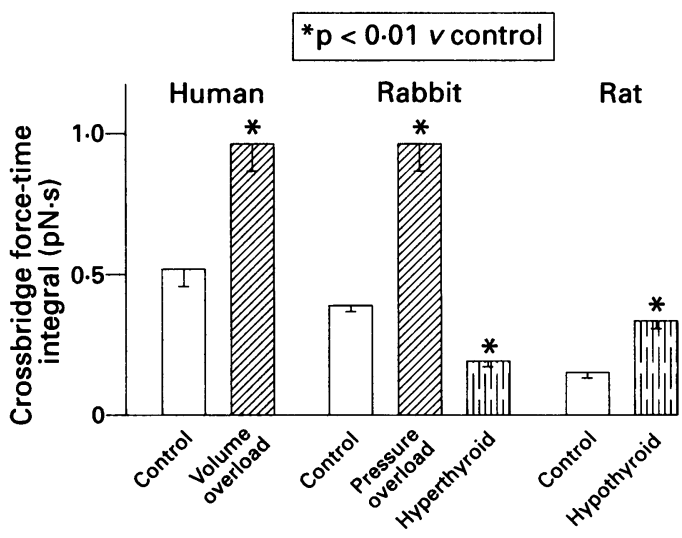

Figure 1 Average crossbridge force-time integral in human, rabbit, and rat myocardium. Differences in crossbridge force-time integral may reflect differences in crossbridge attachment time and are positively related to economy of contraction and negatively related to myofibrillar ATPase activity, shortening velocity, and crossbridge cycling rate. Reproduced with permission. ${ }^{56}$ 
phied or in failing human myocardium. ${ }^{24} 25$ As no shift in the myosin heavy chain isoforms is found in the human ventricular myocardium alterations of crossbridge behaviour may be related to changes in the light chains ${ }^{2627}$ or in thin filament regulatory systems. ${ }^{29}$

The alterations to the behaviour of the individual crossbridge cycle found in the hypertrophied and failing myocardium may have two different consequences to myocardial function: (a) prolonged crossbridge attachment may be beneficial for economy of myocardial contraction, as a greater forcetime integral is produced per unit of high energy phosphate hydrolysed; $(b)$ prolonged crossbridge attachment may result in reduced rates of relaxation and reduced shortening velocity, and may prevent the myocardium from developing high power output. ${ }^{55} 56$ The relevance of altered crossbridge behaviour to systolic or diastolic dysfunction of the failing heart is as yet unknown. It should be mentioned that alterations in crossbridge behaviour similar to those found in the hypertrophied and failing myocardium, occur with aging in patients without heart failure. ${ }^{50}$

\section{EXCITATION-CONTRACTION COUPLING}

From experiments performed in isolated human myocardium, there is considerable evidence that alteration of the excitationcontraction coupling processes may be an important defect in the failing human heart. Excitation-contraction coupling comprises all processes involved in calcium turnover and calcium activation of contractile proteins. ${ }^{6061}$ Calcium, which enters the cell through the $\mathrm{L}$ type voltage gated calcium channel during the action potential, acts on the sarcoplasmic reticulum to release a larger amount of calcium through the ryanodine sensitive calcium release channel. The subsequent calcium binding to the regulatory protein troponin $\mathrm{C}$ facilitates actomyosin interaction. Calcium is removed from the cytosol predominantly by $\mathrm{Ca}^{2+}$ ATPases of the sarcoplasmic reticulum. Also, calcium is removed by the sarcolemmal $\mathrm{Na}^{+}-\mathrm{Ca}^{2+}$ exchanger and by the sarcolemmal $\mathrm{Ca}^{2+}$ ATPase, which, however, seems to be of minor relevance for calcium homeostasis of the myocyte. ${ }^{62} 63$

Recently considerable work has been performed in analysing the function of the various components of the excitation-contraction coupling system in the human heart. It is still unclear whether or not altered density or function of the $L$ type sarcolemmal calcium channel may be relevant to the failing human heart. Dihydropyridine binding studies and functional measurements by voltage clamp techniques indicated unaltered density and properties of this protein. ${ }^{23}$ Molecular biology measurements recently indicated that $\mathrm{mRNA}$ expression of the dihydropyridine receptor is significantly reduced in hearts with dilated or ischaemic cardiomyopathy. ${ }^{4}$ This study also suggested a decreased number of dihydropyridine binding sites in the failing myocardium. ${ }^{4}$

Reduced mRNA expression of the ryanodine receptor (sarcoplasmic reticulum cal- cium release channel) has been found in ischaemic cardiomyopathy, whereas no significant changes in expression have been described in dilated cardiomyopathy. ${ }^{5}$ Functional measurements with a modified voltage-clamp technique of isolated sarcoplasmic reticulum calcium release channels suggested normal function in failing human myocardium from dilated cardiomyopathic hearts. ${ }^{16}$ Another study that used caffein stimulation, however, indicated altered gating properties of this channel in dilated cardiomyopathy. ${ }^{17}$

There are several studies that show that expression of sarcoplasmic reticulum $\mathrm{Ca}^{2+}$ ATPase is reduced at the levels of $\mathrm{mRNA}$ and protein in failing human myocardium from hearts with ischaemic and dilated cardiomyopathy. ${ }^{141819}$ Accordingly, reduced sarcoplasmic reticulum calcium reuptake in the failing human heart was suggested from ${ }^{45} \mathrm{Ca}^{2+}$ uptake measurements in homogenates from human myocardium. ${ }^{20}$ This was not found in another study. ${ }^{21}$ The different results of the two studies may be related to experimental differences, as the first study was performed in ventricular homogenates and the second in highly purified vesicles of the sarcoplasmic reticulum. The activity of the sarcoplasmic reticulum $\mathrm{Ca}^{2+}$ ATPase is controlled by the regulator protein phospholamban. No data are available on phospholamban protein concentrations in the failing human heart; however, recent mRNA measurements indicated that phospholamban may decrease in parallel with sarcoplasmic reticulum $\mathrm{Ca}^{2+}$ ATPase in the failing myocardium. ${ }^{1522}$ Taken together, there is considerable evidence that calcium transport capacity of the sarcoplasmic reticulum may be impaired in the failing human heart, which might be significant pathophysiologically.

From the total amount of calcium cycling during a contraction-relaxation cycle, most is believed to be released and absorbed by the sarcoplasmic reticulum and a little seems to cross the sarcolemmal membrane. This might be different under some pathological conditions when calcium removal by the saroplasmic reticulum is impaired. Reinecke et al showed that at the level of the mRNA and protein, expression of $\mathrm{Na}^{+} \mathrm{Ca}^{2+}$ exchanger is increased, and that there is a significant increase in the ratio of $\mathrm{Na}^{+}-\mathrm{Ca}^{2+}$ exchanger to sarcoplasmic reticulum $\mathrm{Ca}^{2+}$-ATPase protein concentrations in the failing human heart. ${ }^{14}$ This may indicate that under some pathological conditions the relevance of sarcolemmal calcium transport mechanisms increase relative to sarcoplasmic reticulum calcium handling.

Functional alterations in the failing human myocardium

With the photoprotein aequorin, Gwathmey et al showed that at a low temperature $\left(30^{\circ} \mathrm{C}\right)$ and stimulation rate $(0.3 \mathrm{~Hz})$ isometric contractions and $\mathrm{Ca}^{2+}$ intermediaries of muscles from failing hearts were considerably pro- 
Figure 2 Relation between peak twitch tension and stimulation frequency in isolated left ventricular muscle strip preparations from nonfailing and failing human hearts at $37^{\circ} \mathrm{C}$.

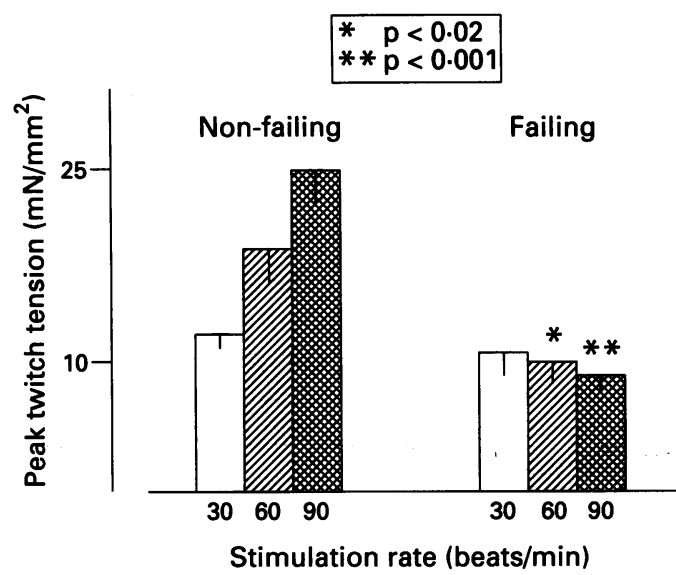

longed and that $\mathrm{Ca}^{2+}$ intermediaries exhibited two distinct components. ${ }^{64}$ Surprisingly, in these experiments twitch tension and peak systolic calcium concentrations were not different between failing and non-failing hearts. ${ }^{64-66}$ When experiments were performed at physiological temperature and rates of stimulation $(\geqslant 1 \mathrm{~Hz})$, twitch tension was significantly reduced in the failing myocardium. ${ }^{50}$ Heat measurements performed in the same study indicated that reduced tension results from a decreased number of contractile proteins activated as a consequence of a reduced amount of calcium cycling. ${ }^{50}$ Accordingly, intracellular calcium measurements in isolated myocytes with Fura-2 showed a pronounced reduction of systolic calcium concentrations and increased diastolic calcium concentrations in the failing human

Figure 3 (A) Influence of heart rate on cardiac index, and $(B)$ maximum rate of left ventricular pressure rise $d P / d t$ max in patients with normal left ventricular function and in patients with dilated cardiomyopathy NYHA class II to III). Heart rate was altered by right ventricular pacing.
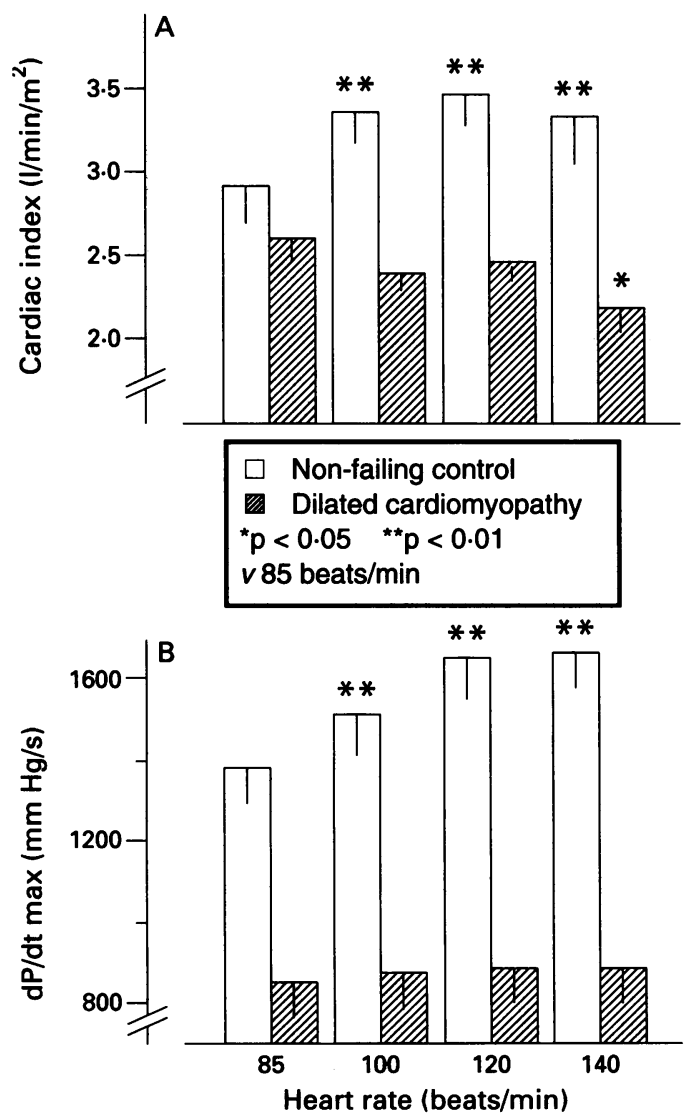

myocardium..$^{67}$

Further experiments on the forcefrequency relation in failing and non-failing human myocardium clearly indicated that discrepant results regarding the development of contractile force in the failing human myocardium may be related to experimental conditions. These experiments showed that with increasing rate of stimulation, twitch tension rises significantly in the non-failing human myocardium, whereas frequency potentiation of contractile force is absent or inverse in the failing heart (fig 2). ${ }^{616869}$ Therefore, intracellular calcium and contractile force are assumed to be similar at low stimulation rates in both the failing and nonfailing myocardium but are significantly reduced in the failing myocardium at higher rates of stimulation. It is important to note that even in the failing myocardium, which shows a pronounced decline in force development at higher stimulation rates, only small changes of diastolic tension were found. ${ }^{70}$

The potential clinical relevance of the altered force-frequency relation in the failing myocardium has been outlined in two studies. It was shown that during right atrial or ventricular pacing the maximum rate of rise in pressure increases at higher heart rates only in patients with normal left ventricular function but does not change in patients with dilated cardiomyopathy..$^{71}$ Furthermore, it was shown that the cardiac index increases at higher, right ventricular pacing rates in patients with normal left ventricular function, and declines in patients with failing dilated cardiomyopathy (fig 3).

As the altered force-frequency relation of the failing human heart may be of pathophysiologial and therapeutic relevance further studies were conducted to evaluate the underlying subcellular defects. With the photoprotein aequorin, we recently showed that in the nonfailing myocardium the frequency dependent increase in contractile force is associated with increasing intracellular calcium concentration and that the inverse force-frequency relation of the failing myocardium goes parallel with a frequency dependent decline of the intracellular calcium signal. ${ }^{73}$ From these findings, there is considerable evidence that disturbed calcium release is an important defect underlying the altered force-frequency relation of the failing human heart. Disturbed calcium release could result from a decreased amount of trigger $\mathrm{Ca}^{2+}$ entering the cell through the $\mathrm{L}$ type $\mathrm{Ca}^{2+}$ channels or from alterations of the ryanodine sensitive sarcoplasmic reticulum calcium release channel. Alternatively, calcium release may be reduced due to decreased sarcoplasmic reticulum calcium uptake, and thus, sarcoplasmic reticulum calcium depletion. From the studies discussed above, there is considerable evidence supporting the second hypothesis. Furthermore, we showed recently that there is a close correlation between the frequency dependent changes in contractile force and the protein concentrations of sarcoplasmic reticulum $\mathrm{Ca}^{2+}$ ATPase. ${ }^{19}$

It should be pointed out that uptake of cal- 
cium into the sarcoplasmic reticulum could also be impaired as a consequence of lack of energy in the failing myocardium, which may result from disturbed mitochondrial function. $^{74}$ This, however, was not obvious from myothermal measurements that indicated unaltered efficiency of metabolic recovery processes in the failing human myocardium..$^{50}$

If an insufficient capacity of the sarcoplasmic reticulum to accumulate calcium at higher rates of stimulation is the cause of reduced systolic calcium release, and thus reduced tension development, one would expect diastolic calcium to rise. This in turn would result in diastolic activation of contractile proteins, and thus would cause a rise in diastolic tension. As even at the highest stimulation frequency the rise of diastolic tension was inconsistent in the failing human myocardium, ${ }^{70}$ alternative mechanisms to remove calcium from the cytosol and prevent diastolic activation of contractile proteins must exist. An alternative to calcium removal by the sarcoplasmic reticulum is that calcium could be removed from the cytosol by mitochondria, which have the potential to accumulate high amounts of calcium and which have been suggested to be involved in the control of intracellular calcium homeostasis. ${ }^{75}$ Furthermore, calcium could be buffered by different intracellular calcium binding proteins such as troponin C or calmodulin. ${ }^{7677}$ Finally calcium could be extruded into the extracellular space by sarcolemmal transport mechanisms such as the sarcolemmal $\mathrm{Ca}^{2+}$ ATPase or the $\mathrm{Na}^{+}-\mathrm{Ca}^{2+}$ exchanger. Recent findings from Reinecke $e t$ al that show increased expression of the $\mathrm{Na}^{+}-\mathrm{Ca}^{2+}$ exchanger in the failing human myocardium suggest that the sarcolemmal $\mathrm{Na}^{+}-\mathrm{Ca}^{2+}$ exchanger may reflect an effective alternative mechanism to remove calcium from the cytosol. ${ }^{14}$ Of course, calcium extruded into the extracellular space is no longer available for activation of contractile proteins during systole. Also, for each calcium ion eliminated by the $\mathrm{Na}^{+}-\mathrm{Ca}^{2+}$ exchanger three $\mathrm{Na}^{+}$ ions enter the cell. Increased calcium elimination by the $\mathrm{Na}^{+}-\mathrm{Ca}^{2+}$ exchanger may, therefore, decrease the membrane potential, which may cause electrical instability and arrhythmias. ${ }^{78}$

\section{Therapeutic interventions}

Which therapeutic implications may be derived from the cellular and subcellular changes in heart failure?

\section{DIURETICS AND VASODILATORS}

Reducing the load of the failing heart with diuretics or vasodilators may reduce the hypertrophic stimulus and myocardial oxygen consumption. Also, haemodynamics are influenced by those agents through their effects on preload and afterload. Accordingly, a reduction of left ventricular hypertrophy during long-term treatment with diuretics and vasodilators has been found in patients with pressure overload due to arterial hypertension. ${ }^{79}$
THE ACE INHIBITORS

The ace inhibitors reduce ventricular load and may reflect a more causal strategy to modulate the pathological changes of the myocardium in congestive heart failure. Accordingly, prevention of left ventricular dilatation after myocardial infarction, prevention of the development of heart failure in patients with left ventricular dysfunction, and improvement of prognosis with long-term ACE inhibitor treatment have been shown in recent large clinical trials. ${ }^{80-82}$

\section{INOTROPIC AGENTS}

The benefit of long-term treatment with inotropic agents that increase cyclic AMP, such as catecholamines and phosphodiesterase inhibitors, is questionable. Moreover, several studies indicated increased mortality of patients with congestive heart failure under long-term treatment with inotropic agents. ${ }^{83-85}$ The reasons for the unfavourable long-term effects of cyclic AMP increasing inotropic agents are speculative, but factors such as increased myocardial oxygen consumption, increased heart rate, and calcium overload of the myocyte may be relevant.

\section{DIGITALIS GLYCOSIDES}

In contrast with catecholamines and phosphodiesterase inhibitors, the cyclic AMP independent digitalis glycosides seem to have favourable effects on symptoms and haemodynamics during long-term treatment in patients with congestive heart failure.$^{86-88}$ This might in part result from the decrease in sympathetic tone, increase in parasympathetic tone, reduction of heart rate, and increase in inotropic state.

\section{$\beta$-ADRENOCEPTOR BLOCKER}

$\beta$ Adrenoceptor blockers have been shown to improve haemodynamics, exercise capacity, and symptoms in patients with congestive heart failure. ${ }^{89} 90$ Although in earlier studies beneficial effects of $\beta$ blocker treatment were supposed to be related to upregulation of $\beta$ adrenoceptors in the failing myocardium, it was shown more recently that the beneficial effects are present regardless of $\beta$ receptor upregulation. $^{9192}$ The beneficial effects of $\beta$ blockers may result from the protection of the myocardium from the increased sympathetic tone. Also, a reduction in heart rate may contribute to the beneficial effects of those agents. In most studies, higher resting heart rates seem to favour a beneficial response to $\beta$ blocker treatment. ${ }^{90}$ Moreover it was shown that increased heart rate is most predictive of a favourable clinical response to $\beta$ adrenoceptor blockade with metoprolol in patients with dilated cardiomyopathy. ${ }^{93}$

\section{REDUCTION IN HEART RATE}

Reduction in heart rate itself may be a promising therapeutic approach in congestive heart failure. Reduction of heart rate in patients with impaired left ventricular function may be beneficial from four perspectives: (a) due to the inversion of the force-frequency relation, 
intrinsic contractile force of the myocardium may increase; (b) myocardial oxygen consumption, which is proportional to heart rate, decreases; (c) time available for diastolic chamber filling is prolonged; and $(d)$ time available for coronary perfusion is prolonged. Reduction in heart rate may be obtained by application of $\beta$ adrenoceptor blockers, digitalis glycosides, or amiodarone. ${ }^{94}$ Also, a new class of heart rate reducing agents, the so called sinus node inhibitors, which act by direct effects on pacemaker currents, are now under clinical investigation. ${ }^{95}$

1 McKee PA, Castelli WP, McNamara P, Kannel WP. The natural history of congestive heart failure: the Framingham study. $N$ Engl $\Im$ Med 1971;285:1441-6.

2 Rasmussen PR, Minobe W, Bristow MR. Calcium antagonist binding sites in failing and non-failing human ventricular myocardium. Biochem Pharmacol 1990;39. 691-6.

3 Beuckelmann DJ, Erdmann E. $\mathrm{Ca}^{2+}$-currents and intracellulart $\mathrm{Ca}^{2+}$-transients in single ventricular myocytes isolated from terminally failing human myocardium. In: isolated from terminally failing human myocardium. In: Cellular and molecular alterations in the failing human Cellular and molecular alterations in the failing human heart. Darmstadt

4 Takahashi T, Allen PD, Marks AR, Deniss AR, Schoen FJ, Grossman W, Marsh JD, Izumo S. Expression of dihydropyridine receptor ( $\mathrm{Ca}^{2+}$-channel) and calsequestrin genes in the myocardium of patients with endstage heart failure. $\mathcal{F}$ Clin Invest 1992;90:927-35.

5 Brillantes AM, Allen P, Takahashi T, Izumo S, Marks AR. Differences in cardiac calcium release channels (ryanodien receptor) expression in myocardium from patients dilated cardiomyopathy. Circ Res 1992;71:18-26.

6 Bristow MR, Feldmann AM. Changes in the receptor-G protein-adenylyl cyclase system in heart failure from various types of heart muscle disease. In: Hasenfuss $G$, Holubarsch $\mathrm{Ch}$, Just $\mathrm{H}$, Alpert NR, eds. Cellular and molecular alterations in the failing human heart. Darmstadt: molecular alterations in the failing human heart. Darm

7 Böhm M, Gierschik P, Jakobs KH, Pieske B, Schnabel P, Ungerer $M$, Erdmann $E$. Increase of $G_{i a}$ in human hearts with dilated but not ischemic cardiomyopathy. Circulation 1990;82:1249-65.

8 Neumann J, Schmitz W, Scholz H, von Meyerinck L, Döring V, Kalmar P. Increase in myocardial $\mathrm{G}_{\mathrm{i}}$-proteins in heart failure. Lancet 1988;22:936-7.

9 Feldman AM, Cates AE, Veazey WB, Hershberger RE, Bristow MR, Baughman $\mathrm{KL}$, et al. Increase of the 40,000-mol wt pertussis toxin substrate (G-protein) in the failing human heart. $\mathcal{F}$ Clin Invest 1988;82:189-97.

10 Böhm M, Gierschik P, Erdmann E. Quantification of $G_{i \text { i }}$ proteins in the failing and nonfailing human myocardium. In: Hasenfuss $\mathrm{G}$, Holubarsch $\mathrm{Ch}$, Just $\mathrm{H}$, myocardium. In: Hallufuss $\mathrm{G}$, Holubarsch Ch, Just $\mathrm{H}_{\text {, }}$ Alpert NR, eds. Cellular and molecular alterations in the failing human heart. Darms

11 Eschenhagen T, Mende U, Nose M, Schmitz W, Scholz $\mathrm{H}$, Haverich A, et al. Increased messenger RNA level of the inhibitory $\mathrm{G}$ protein $a$ subunit $\mathrm{G}_{\mathrm{i} a-2}$ in human endstage heart failure. Circ Res 1992;70:688-96.

12 Schnabel P, Böhm M, Gierschik P, Jakobs KH, Erdmann E. Improvement of cholera toxin-catalyzed ADP-ribosilation by endogenous ADP-ribosylation factor from bovine brain provides evidence for an unchanged
amount of $G_{a}$ in failing human myocardium. $₹ \mathrm{Mol} \mathrm{Cell}$ Cardiol 1990;22:73-82.

13 Allen PD, Schmidt TA, Marsh JD, Kjeldsen K. Na, KATPase expression in normal and failing human left ventricle. In: Hasenfuss $G$, Holubarsch $\mathrm{Ch}$, Just $\mathrm{H}$, ventricle. In: Hasenfuss $\mathrm{G}$, Holubarsch $\mathrm{Ch}$, Just $\mathrm{H}$, Alpert NR, eds. Cellular and molecular alterations in the
failing human heart. Darmstadt: Steinkopff and New failing human heart. Darms

14 Reinecke H, Studer R, Philipson KD, Bilger J, Eschenhagen T, Böhm M, et al. Myocardial gene expression of $\mathrm{Na}^{+}-\mathrm{Ca}^{2+}$-exchanger and sarcoplasmic reticulum $\mathrm{Ca}^{2+}$-ATPase in human heart failure. Circulation 1992;86(suppl I):I-860.

15 Arai M, Alpert NR, MacLennan DH, Barton P, Periasami $M$. Alterations in sarcoplasmic reticulum gene expression in human heart failure: a possible mechanism for alterations in systolic and diastolic properties of the failin myocardium. Circ Res 1993;72:463-9.

16 Holmberg S, Williams AJ. Single channel recordings from human cardiac sarcoplasmic reticulum. Circ Res 1989 65:1445-9.

17 D'Angelo A, Luciani GB, Mazzucco A, Gallucci V, ity of the sarcoplasmic reticulum in dilated cardiomy- opathy. Circulation 1992;85:518-25.

18 Mercadier J, Lompre AM, Duc P, Boheler KR, Fraysse JB, Wisnewsky C, et al. Altered sarcoplasmic reticulum $\mathrm{Ca}^{2+}$-ATPase gene expression in the human ventricle during end-stage heart failure. $\mathcal{f}$ Clin Invest 1990;85: 305-9.

19 Hasenfuss G, Reinecke H, Studer R, Pieske B, Holtz J, Holubarsch $\mathrm{Ch}$, et al. Relationship between myocardial function and expression of sarcoplasmic reticulum calcium-ATPase in failing and nonfailing human myocardium. f Mol Cell Cardiol 1993;25:17.

20 Limas CJ, Olivari M, Goldenberg JF, Levine TB, Bendit DG, Simon A. Calcium uptake by cardiac sarcoplasmic reticulum in human dilated cardiomyopathy. Cardiovasc Res 1987;21:601-5.

21 Movsesian MA, Bristow MR, Krall J. $\mathrm{Ca}^{2+}$ uptake by cardiac sarcoplasmic reticulum from patients with idiopathic dilated cardiomyopathy. Circ Res 1989;65: pathic $1141-4$.

22 Feldman AM, Ray PE, Silan CM, Mercer JA, Minobe W, Bristow MR. Selective gene expression in failing human heart. Quantification of steady-state levels of messenger hNA in endomyocardial biopsies using the polymerase RNA in endomyocardial biopsies using the
chain reaction. Circulation 1991;83:1866-72

23 Mercadier JJ, de la Bastie D, Ménasché $P$, N'Guyen van Cao a, Bouveret $P$, Lorente $P$, et al. Alpha myosin heavy chain isoform and atrial size in patients with various types of mitral valve dysfunction: a quantitative study. $\mathcal{F}$ Am Coll Cardiol 1987;9:1024-30.

24 Mercadier JJ, Bouveret P, Gorza L, Schiaffino S, Clark WA, Zak R, et al. Myosin isoenzymes in normal and hypertrophied human ventricular myocardium. Circ Res 1983;53:52-62.

25 Gorza L, Mercadier JJ, Schwartz K, Thornell LE, Sartore S Schiaffino S. Myosin types in the human heart. Circ Res 1984;54:694-702.

26 Hirzel HO, Tuchschmid CR, Schneider J, Krayenbueh HP, Schaub MC. Relationship between myosin isoenzyme composition, hemodynamics and myocardial structure in various forms of human cardiac hypertrophy. Circ Res 1985;57:729-40.

27 Margossian SS, White HD, Caulfield JB, Norton P, Taylor S, Slayter HS. Light chain 2 profile and activity of human ventricular myosin during dilated cardiomyopathy. Identification of a causal agent for impaired myocardial function. Circulation 1992;85:1720-33.

28 Boheler KR, Carrier L, de la Bastie D, Allen PD, Komajda M, Mercadier JJ, Schwartz K. Skeletal actin mRNA increases in the human heart during oncogenic development and is the major isoform of control and failing ment and is the major isoform of control
adult hearts. $\mathcal{f}$ Clin Invest 1991;88:323-30.

29 Anderson PAW, Malouf NN, Oakeley AE, Pagani ED, Allen PD. Troponin T isoform expression in humans: a
comparison among normal and failing adult heart, fetal heart, and adult and fetal skeletal muscle. Circ Res heart, and adult
$1991 ; 69: 1226-33$.

30 Anderson PAW, Malouf NN, Oakeley AE, Pagani ED, Allen PD. Troponin T expression in the normal and failing human left ventricle: a correlation with myofibrillar ATPase activity. In: Hasenfuss $\mathrm{G}$, Holubarsch $\mathrm{Ch}$, Just failing human heart. Darmstadt: Steinkopff, and New York: Springer, 1992:117-27.

31 Izumo S, Nadal-Ginard B, Mahdavi V. Protooncogene induction and reprogramming of cardiac gene expression produced by pressure overload. Proc Natl Acad Sci sion produced by
$1988 ; 85: 339-43$.

32 Komuro I, Kurabayashi M, Takaku F, Yazaki Y. Expression of cellular oncogenes in the myocardium
during the developmental stage and pressure-overloaded during the developmental stage and pressure-overloaded
hypertrophy of the rat heart. Circ Res 1988;62:1075-9.

33 Mulvagh SL, Michael LH, Perryman MB, Roberts R Schneider MD. A hemodynamic load in vivo induces cardiac expression of the cellular oncogene c-myc. Biochem Biophys Res Commun 1987;147:627-36.

34 Simpson P. Norepinephrine-stimulated hypertrophy of cultured rat myocardial cells in an alpha $a_{1}$-adrenergic response. F Clin Invest 1983;72:732-8.

35 Long CS, Kariya K, Karns L, Simpson PC. Sympathetic modulation of the cardiac myocyte phenotype: studies with cell-culture model of myocardial hypertrophy. Basic Res Cardiol 1992;87:19-31.

36 Stanton HC, Brenner G, Mayfield ED Jr. Studies on isoproterenol-induced cardiomegaly in rats. Am Heart $\mathcal{F}$ proterenol-induced

37 Parkert TG, Schneider MD. Peptide growth factors can provoke "fetal" contractile protein gene expression in rat
cardiac myocytes. $¥$ Clin Invest $1990 ; 85: 507-14$.

38 Schneider MD, McLellan WR, Black FM, Parker TG Growth factors, growth factor response elements, and the cardiac phenotype. Basic Res Cardiol 1992;87:33-48.

39 Komuro I, Kaida T, Shibazaki Y, Kurabayashi M, Katoh Y, Hoh E, et al. Stretching cardiac myocytes stimulates protooncogene expression. $f$ Biol Chem 1990;265: 3595-8.

40 Komuro I, Katoh Y, Kaida T, Shibazaki Y, Kurabayash M, Hoh E, et al. Mechanical loading stimulates cell hypertrophy and specific gene expression in cultured rat cardiac myocytes. 7 Biol Chem 1991;265:1265-8.

41 Yazaki Y, Komuro I. Role of protein kinase system in the signal transduction of stretch-mediated myocyte growth. Basic Res Cardiol 1992;87:11-8.

42 Sadoshima J, Izumo S. Molecular characterization of angiotensin II-induced hypertrophy of cardiac myocytes and hyperplasia of cardiac fibroblasts. Critical role of 
The $\mathrm{AT}_{1}$ receptor subtype. Circ Res 1993;73:413-23.

43 Sadoshima J, Izumo S. Signal transduction pathways of angiotensin II-induced c-fos gene expression in cardiac myocytes in vitro. Roles of phospholipid-derived second messengers. Circ Res 1993; 73:424-38.

44 Ganten D, Mullins J, Lindpainter $K$. The tissue reninangiotensin system: a target for angiotensin-converting enzyme inhibitors. $₹$ Hum Hypertens 1989;3:63-70.

45 Lindpainter $K$, Ganten $D$. The cardiac renin-angiotensin system. An appraisal of present experimental and clinica evidence. Circ Res 1991;68:905-2

46 Baker KM, Chernin MI, Wixson SK, Aceto JF. Reninangiotensin system involvement in pressure overload cardiac hypertrophy in rats. Am f Physiol 1990;259. 324-32.

47 Schunkert H, Dzau VJ, Tang SS, Hirsch AT, Apstein CS, Lorell $\mathrm{BH}$. Increased rat cardiac angiotensin-converting enzyme activity and mRNA expression in pressure-overload left ventricular hypertrophy. $\mathcal{F}$ Clin Invest 1990;86: 1913-20.

48 Studer R, Müller B, Reinecke H, Just H, Holtz J, Drexler $H$. Quantified RNA-polymerase chain reaction demonstrated augmented gene expression of angiotensin converting enzyme in ventricles of patients with heart verting enzyme in ventricles of

49 Weber KT, Brilla CG. Factors associated with reactive and reparative fibrosis of the myocardium. In: Hasenfus G, Holubarsch CH, Just H, Alpert NR, eds. Cellular and molecular alterations in the failing human heart. Damstadt: Steinkopff, and New York: Springer, 1992:291-301.

50 Hasenfuss G, Mulieri LA, Leavitt JB, Allen PD, Haeberle JR, Alpert NR. Alteration of contractile function and excitation-contraction coupling in dilated cardiomyopathy. Circ Res 1992;70:1225-32.

51 Hamrell BB, Alpert NR. The mechanical characteristics of hypertrophied rabbit cardiac muscle in the absence of congestive heart failure. Circ Res 1977;40:20-5.

52 Holubarsch $\mathrm{Ch}$, Goulette RP, Litten RZ, Martin BJ, Mulieri LA, Alpert NR. The economy of isometric force development, myosin isoenzyme pattern and myofibrildevelopment, myosin isoenzyme pattern and myofibrilmyocardium. Circ Res 1985;56:78-86.

53 Swynghedauw B. Developmental and functional adaptation of contractile proteins in cardiac and skeletal muscles. Physiol Rev 1986;66:710-71.

54 Maughan D, Low E, Litten R, Brayden J, Alpert NR Calcium-activated muscles from hypertrophied rabbi hearts: mechanical and correlated biochemical changes. Circ Res 1979;44:279-87.

55 Alpert NR, Mulieri LA. Increased myothermal economy of isometric force development in compensated cardiac hypertrophy induced by pulmonary artery constriction in the rabbit. Circ Res 1982;50:491-500.

56 Hasenfuss G, Mulieri LA, Blanchard EM, Holubarsch Ch, Leavitt BJ, Ittleman F, Alpert NR. Energetics of isometric force development in control and volume overload human myocardium. Comparison with animal species. Circ Res 1991;68:836-46.

57 Hajiar RJ, Gwathmey JK. Cross-bridge dynamics in human ventricular myocardium. Regulation of contractility in the failing heart. Circulation 1992;86:1819-926.

58 Pagani ED, Alois AA, Grant AM, Older TM, Dziuban SW, Allen PD. Changes in myofibrillar content and $\mathrm{Mg}$ ATPase activity in ventricular tissue from patients with heart failure caused by coronary artery disease, cardiomyopathy, or

59 Alpert NR, Gordon MS. Myofibrillar adenosine triphosphatase activity in congestive heart failure. Am $\mathcal{f}$ Physio 1962;202:940-6.

60 Barry WH, Bridge JHB. Intracellular calcium homeostasis in cardiac myocytes. Circulation 1993;87:1806-15.

61 Hasenfuss G, Mulieri LA, Holubarsch Ch, Pieske B, Just $H$, Alpert NR. Energetics of calcium cycling in nonfailing and failing human myocardium. Basic Res Cardiol ing and failing

62 Philipson $\mathrm{KD}$. The cardiac $\mathrm{Na}^{+}-\mathrm{Ca}^{2+}$-exchanger. In: Langer GA ed. Calcium and the heart. New York, Raven Press, 1990:85-108.

63 Carafoli $\mathrm{E}$. The homeostasis of calcium in heart cells. $\mathscr{f}$ Mol Cell Cardiol 1985;17:203-12.

64 Gwathmey JK, Copelas L, Mackinnon R, Schoen FJ, Feldman MD, et al. Abnormal intracellular calcium handling in myocardium from patients with end-stage hear failure. Circ Res 1987;61:70-6.

65 Gwathmey JK, Slawsky MT, Hajjar RJ, Briggs GM Morgan JP. Role of intracellular calcium handling in force interval relationship of human ventricular myocardium. $\mathcal{F}$ Clin Invest 1990;85:1599-613.

66 Morgan JP. Abnormal intracellular modulation of calcium as a major cause of cardiac contractile dysfunction. $N$ Engl ₹ Med 1991;325:625-32.

67 Beuckelmann DJ, Näbauer M, Erdmann E. Intracellula calcium handling in isolated ventricular myocytes from patients with terminal heart failure. Circulation 1992; 85:1046-55.

68 Mulieri LA, Hasenfuss G, Leavitt BJ, Allen PD, Alper NR. Altered myocardial force-frequency relation in human heart failure. Circulation 1992;85:1743-50.

69 Pieske B, Hasenfuss G, Holubarsch Ch, Schwinger R Böhm M, Just $\mathrm{H}$. Alterations of force-frequency-relationship in the failing human heart depend on the underlying cardiac disease. In: Hasenfuss $\mathrm{G}$, Holubarsch $\mathrm{Ch}$,
Just $\mathrm{H}$, Alpert NR, eds. Cellular and molecular alterations in the failing human heart. Darmstadt: Steinkopff, and New York: Springer, 1992:213-21.

70 Mulieri LA, Leavitt BJ, Hasenfuss G, Allen PD, Alpert NR. Contraction frequency dependence of twitch and diastolic tension in human dilated cardiomyopathy. In: Hasenfuss G, Holubarsch $\mathrm{Ch}$, Just $\mathrm{H}$, Alpert NR, eds. Cellular and molecular alterations in the failing human Cellular and molecular alterations in the failing human heart. Da.

71 Feldman MD, Alderman JR, Aroesty JM, Royal HD Ferguson JJ, Owen RM, et al. Depression of systolic and diastolic myocardial reserve during atrial pacing tachycardia in patients with dilated cardiomyopathy. $₹$ Clin Invest 1988;82:1661-9.

72 Hasenfuss G, Holubarsch $\mathrm{Ch}$, Hermann HP, Astheime $K$, Pieske $B$, Just $H$. Influence of the force-frequency relation on hemodynamics and left ventricular function in patients with nonfailing hearts and in patients with failing dilated cardiomyopathy. Eur Heart $\mathcal{F}$ 1994;15:164-70.

73 Pieske B, Kretschmann B, Schmidt-Schweda S, Minami $\mathrm{K}$, Posival H, Holubarsch Ch, et al. The force-frequency relationship in the human non-failing and failing myocardium depend on changes in the intracellular calcium concentration. $¥ \mathrm{Mol}$ Cell Cardiol 1993;25(supp 1):12.

74 Schulze K, Becker BF, Schauer R, Schultheiss HP Antibodies to ADP-ATP carrier-an autoantigen in myocarditis and dilated cardiomyopathy-impair cardiac function. Circulation 1990;81:959-69.

75 Crompton $\mathrm{M}$. The role of $\mathrm{Ca}^{2+}$ in the function and dysfunction of heart mitochondria, In: Langer GA ed. Calcium and the heart. New York: Raven Press, 1990:167-198.

76 Robertson SP, Johnson JD, Potter JD. The time-course of $\mathrm{Ca}^{2+}$ exchange with calmodulin, troponin, parvalbumin and myosin in response to transient increases in $\mathrm{Ca}^{2+}$ Biophys $₹$ 1981;34:559-69.

77 Holroyde MJ, Robertson SP, Johnson JD, Solaro RJ, Potter JD. The calcium and magnesium binding sites on Potter JD. The calcium and magnesium binding sites on cardiac troponin and their role in the regulation of myofibrillar adenos

78 Lakatta EG. Functional implications of spontaneous sarcoplasmic reticulum $\mathrm{Ca}^{2+}$ release in the heart Cardiovasc Res 1992;26:193-21

79 Georgiou D, Brundage B. Regression of left ventricula mass in systemic hypertension. Clin Cardiol 1992;15: 5-16.

80 The SAVE-Investigators. Effect of captopril on mortality and morbidity in patients with left ventricular dysfunction after myocardial infarction. Restuls of the survival and ventricular enlargement trial. $N$ Engl $f$ Med 1992;327:669-77.

81 The SOLVD-Investigators. Effect of enalapril on survival in patients with reduced left ventricular ejection fraction and congestive heart failure. $N$ Engl $f$ Med 1991;325: and cong 302 .

82 Pouleur H, Rousseau MF, van Eyll $\mathrm{Ch}$, Stoleru L Hayashida W, Udelson JA, et al (SOLVD Investigators) Effects of long-term enalapril therapy on left ventricula diastolic properties in patients with depressed ejection fraction. Circulation 1993;88:481-91.

83 Packer M, Carver JR, Rodeheffer RJ, Ivanhoe RJ, DiBianco R, Zeldis SM, et al. (The PROMISE Study in severe chronic heart failure. $N$ Engl f Med 1991;325: 1468-75.

84 Dies F, Krell MJ, Whitlow P, Liang C, Goldenberg I, Appelfeld MM, Gilbert EM. Intermittent dobutamine in ambulatory outpatients with chronic cardiac failure. Circulation 1986;74:38.

85 Uretski BF, Jessup M, Konstam MA, Dec GW, Leier CV Benotti J, et al. (The ENOXIMONE Multicenter Tria Group). Multicenter trial of oral enoximone in patients with moderate to moderately severe congestive heart failwith moderate to moderately severe congestive heart failure. Lack of ben

86 Jaschke $R$, Oxman $A D$, Guyatt $G H$. To what extent do congestive heart failure patients in sinus thythm benefit from digoxin therapy? A systematic overview and metaanalysis. Am $\mathcal{F}$ Med 1990;88:279-86.

87 Packer M, Gheorghiade M, Young JB, Constantini PJ Adams KF, Cody RJ, et al (the RADIANCE study) Withdrawal of digoxin from patients with chronic heart failure treated with angiotensin-converting-enzym inhibitors. N Engl F Med 1993;329:1-7.

88 Uretzky BF, et al. Randomized study assessing the effect of digoxin withdrawal in patients with mild to moderate chronic congestive heart failure: results of the PROVED trial. ₹ Am Coll Cardiol 1993;22:955-62.

89 Jessup M. Beta-adrenergic blockade in congestive heart failure: answering the old question. $\mathcal{F} \mathrm{Am}$ Coll Cardiol 1991;18:1067-9.

90 Charlap S, Lichstein E, Frishman WH. $\beta$-adrenergic blocking drugs in the treatment of congestive heart failure. Med Clin North Am 1989;73:373-85.

91 Heilbrunn $S M$ Shah $P$ Bristow MR, Valantine HA Ginsburg R, Fowler MB. Increased $\beta$-receptor densitiy and improved hemodynamic response to catecholamin stimulation during long-term metoprolol therapy in heart failure from dilated cardiomyopathy. Circulation 1989;79:483-90.

92 Gilbert EM, Olsen SL, Mealey P, Volkman K, Larrabee P, 
Bristow MR. Is beta-receptor up-regulation necessary for improved LV-function in dilated cardiomyopathy? Circulation 1991;84:469.

93 Engelmeier RS, O'Connell JB, Walsh R, Rad N, Scanlon PJ, Gunor RM. Improvements in symptoms and exercise tolerance by metoprolol in patients with dilated cardiomyopathy: a double-blind, randomized, placebo- controlled trial. Circulation 1985;3:536-46.

94 Hamer AWF, Arkles LB, Johns JA. Beneficial effects of low dose amiodarone in patients with congestive heart failure: a placebo controlled trial. $f \mathrm{Am}$ Coll Cardio

1989;14:1768-74.
95 Hjalmarson A, Remme WJ, eds. Sinus node inhibitors. Darmstadt: Steinkopff, and New York: Springer, 1991. 